\title{
Extract of Stellerachamaejasme L(ESC) inhibits growth and metastasis of human hepatocellular carcinoma via regulating microRNA expression
}

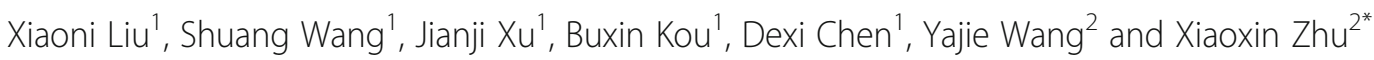

\begin{abstract}
Background: MicroRNAs(miRNAs)are involved in the initiation and progression of hepatocellular carcinoma. ESC, an extract of Stellerachamaejasme $L$, had been confirmed as a potential anti-tumor extract of Traditional Chinese Medicine. In light of the important role of miRNAs in hepatocellular carcinoma, we questioned whether the inhibitory effects of ESC on hepatocellular carcinoma (HCC) were associated with miRNAs.

Methods: The proliferation inhibition of ESC on HCC cells was measured with MTT assay. The migration inhibition of ESC on HCC cells was measured with transwell assay. The influences of ESC on growth and metastasis inhibition were evaluated with xenograft tumor model of HCC. Protein expressions were measured with western blot and immunofluorescence methods and miRNA profiles were detected with miRNA array. Differential miRNA and target mRNAs were verified with real-time PCR.

Results: The results showed that ESC could inhibit proliferation and epithelial mesenchymal transition (EMT) in HCC cells in vitro and tumor growth and metastasis in xenograft models in vivo. miRNA array results showed that 69 differential miRNAs in total of 429 ones were obtained in MHCC97H cells treated by ESC. hsa-miR-107, hsa-miR-638, hsa-miR-106b-5p were selected to be validated with real-time PCR method in HepG2 and MHCC97H cells. Expressions of hsa-miR-107 and hsa-miR-638 increased obviously in HCC cells treated by ESC. Target genes of three miRNAs were also validated with real-time PCR. Interestingly, only target genes of hsa-miR-107 changed greatly. ESC downregulated the MCL1, SALL4 and BCL2 gene expressions significantly but did not influence the expression of CACNA2D1.
\end{abstract}

Conclusion: The findings suggested ESC regressed growth and metastasis of human hepatocellular carcinoma via regulating microRNAs expression and their corresponding target genes.

Keywords: Hepatocellular carcinoma, microRNA, Stellerachamaejasme L, Target gene, MCL1, SALL4, BCL2

\section{Background}

MicroRNAs (miRNAs) are small non-coding RNAs characterized by a length of $18-25$ nucleotides and capable of binding to complementary 3'UTR regions of their target genes, thereby modulating the transcription of the target mRNA [1]. Mounting evidences have demonstrated that miRNAs are involved in the initiation and

\footnotetext{
* Correspondence: zhuxx59@163.com

${ }^{2}$ Institute of Chinese Materia Medica, China Academy of Chinese Medical Sciences, No 16 Nan Xiao Jie, Dong Zhi Men Nei, Dong Cheng Qu, Beijing 100700, China

Full list of author information is available at the end of the article
}

progression of several types of human cancer, including hepatocellular carcinoma (HCC), which is one of the most common types of cancer and the third leading cause of cancer-related mortality worldwide [2]. It was recently demonstrated that miRNAs played critical roles in HCC progression and directly contributed to tumor cell proliferation, avoidance of apoptotic cell death and metastasis by targeting a large number of specific mRNAs. miRNAs may undergo aberrant regulation during carcinogenesis and act as oncogenes or tumor suppressor genes in HCC [3-6]. 
ESC, an extract of StellerachamaejasmeL, rich in isomers of Chamaejasminor, neochamaejasmine and Sikokianin [7], had antitumor effects by activating apoptosis pathway and reversed EMT of tumor cells induced by TGF- $\beta$ via inhibition of Smad signaling pathway in our previous studies $[8,9]$. ESC had been confirmed as a potential anti-tumor extract of Traditional Chinese Medicine.

In light of the important role of miRNAs in hepatocellular carcinoma, we questioned whether the inhibitory effects of ESC on hepatocellular carcinoma were associated with miRNAs. To figure out this question, this study was performed to evaluate modulatory effect of ESC on miRNAs expression in hepatocellular carcinoma in order to clarify the molecular mechanisms of ESC on hepatocellular carcinoma.

\section{Methods}

\section{Preparation of ESC}

ESC was provided and identificated by Hong Bin Xiao (China Academy of Chinese Medical Sciences, Beijing, People's Republic of China), which has been deposited in Institute of Chinese Materia Medica, China Academy of Chinese Medical Sciences(Deposition number:ICMM001). The extract method was as follows: Stellerachamaejasme $L$ herbal medicine was extracted 3 times with ethanol. Meanwhile, the concentrated liquid (volatile to non-alcohol taste) was washed on a polyamide column with $60 \%$ ethanol, and then decompressively recycled and vacuum dried at room temperature. The final compound obtained was ESC.

\section{Reagents and antibodies}

Trypsin-ethylene-diaminetetraacetic acid and DMEM medium were purchased from Gibco (Grand Island, NY, USA); Fetal bovine serum was from China Hangzhou Sijiqing Biological Technology Co.,Ltd.; 3-(4,5-dimethyl-2thiazolyl)-2,5-diphenyl-2-H-tetrazolium bromide (MTT) and dimethylsulfoxide (DMSO) were provided by Sigma Chemical Co. (St. Louis, MO,USA); Caspase 3, E-cadherin, Vimentin and $\beta$-actin primary monoclonal antibody were purchased from Abcam Ltd. (Cambridgem MA, USA); Matrigel was from BD Biosciences (Los Angeles, CA, USA); Crystal violet was from Beijing Solarbio Science and Technology Co., Ltd.; Trizoland SuperScript ${ }^{\mathrm{Tm}}$ III Reverse Transcriptase was from Invitrogen; RT Primers were synthesized by Invitrogen Biotechnology Co. Ltd.; PCR kit was from Arraystar INC. miRCURYTM Array Power Labeling kit and miRCURY ${ }^{\mathrm{TM}}$ Array were from Exiqon.

\section{Cell line and cell culture}

HepG2, HepG2-luc and MHCC97H liver cancer cell lines were preserved in Beijing Institute of Hepatology. Cells were cultured in DMEM medium supplemented with $10 \%$ fetal bovine serum and maintained at $37^{\circ} \mathrm{C}$ in a humidified incubator with 5\% CO2.

\section{Animals and animal feeding}

Four-week-old male balb/c nude mice (from Beijing Vital River Laboratory Animal Technology Co. Ltd) were raised and maintained in individually ventilated cages (IVC) under specific pathogen free sterile condition.

\section{MTT assay}

Cells in the logarithmic growth phase were plated in 96-well plates in a seeding density of 2500-3000 cells per well and incubated in a $37{ }^{\circ} \mathrm{C}$ incubator with $5 \%$ $\mathrm{CO} 2$ overnight. After cells were treated with different concentration ESC for 24, 48, $72 \mathrm{~h}$, the culture medium in each well was abandoned, incubating with $0.5 \mathrm{~g} / \mathrm{L}$ MTT $100 \mu \mathrm{L}$ for $4 \mathrm{~h}$. Then each well was added with $150 \mu \mathrm{L}$ DMSO and vibrated for $10 \mathrm{~min}$, and absorbance of each well was detected with microplate reader (ELX800 type, BIO-TEX Instruments, INC, Winooski, VT, USA) at the $490 \mathrm{~nm}$ wave length. The inhibition rate (IR) was calculated as follows: IR $(\%)=\left(1-\mathrm{OD}_{\text {treatment }} /\right.$ $\left.\mathrm{OD}_{\text {control }}\right) \times 100 \%$. Half-maximal inhibitory concentration $\left(\mathrm{IC}_{50}\right)$ was determined by logistic method.

\section{Transwell assay}

The migration experiment was analyzed in 24-well transwell plates (Corning Incorporated). $2 \times 10^{4}$ cells in $100 \mu \mathrm{L}$ of DMEM medium with $1 \%$ BSA and different concentrations of ESC were added to the top chamber and $500 \mu \mathrm{L}$ of $10 \%$ serum-containing DMEM was added in the bottom chamber. The cells were then incubated at $37^{\circ} \mathrm{C}$ with $5 \% \mathrm{CO} 2$ for $24 \mathrm{~h}$. After incubation, the medium was removed, and non-invading cells were scrubbed by a wet cotton swab. The invading cells were washed by PBS for three times and fixed by $4 \%$ paraformaldehyde for $15 \mathrm{~min}$. Fixed cells were washed three times by PBS and stained by $0.1 \%$ crystal violet in PBS for $10 \mathrm{~min}$. Excess stain was washed by distilled water for three times. The migration cells were counted in five random fields in the same area for unbiased measurement using an inverted microscope.

\section{Western blot assay}

Cells were seeded in $100 \mathrm{~mm}$ tissue culture dishes at the density of $2 \times 10^{6}$ cells per dish and incubated for overnight. Cells were then treated with various agents as indicated in figure legends, then washed with ice-cold PBS and harvested in $400 \mu \mathrm{L}$ of cell lysis buffer. The protein concentrations of lysates were determined using the bicinchonininc acid method. Cell lysates (40 $\mu \mathrm{g}$ protein per lane) were separated using 10\% SDS-PAGE and transferred electrophoretically to polyvinylidenediluoride membrane. Membranes were blocked with tris-buffered 
saline $/ 0.1 \%$ tween 20 containing $5 \%$ bovine serum albumin and then incubated overnight at $4{ }^{\circ} \mathrm{C}$ with primary antibodies (1:1000). Membranes were washed three times with TBST and incubated for $1 \mathrm{~h}$ at room temperature with the appropriate secondary antibody conjugated to goat anti-rabbit horseradish peroxidase (1:2000). Membranes were then washed and immunoreactive bands were developed with ECL and visualized by autoradiography. Protein loading was normalized using $\beta$-actin antibody. Gray-scale analysis of protein bands was performed using image software.

\section{Immunofluorescence analysis}

Cells were seeded into 24-well plates and treated as described as figure legends. Cells were fixed with $4 \%$ formaldehyde for $30 \mathrm{~min}$, washed with PBS, blocked with 5\% BSA for $30 \mathrm{~min}$ at room temperature, and then stained with anti-human primary antibody (1:100) at $4{ }^{\circ} \mathrm{C}$ overnight. Cells were incubated with anti-rabbit-FITC secondary antibody (1:500) for $2 \mathrm{~h}$ at $4{ }^{\circ} \mathrm{C}$, and then washed with PBS. Cells were then incubated for $10 \mathrm{~min}$ at room temperature with DAPI to stain nuclei, washed twice with PBS, and observed using an inverted fluorescence microscope (Olympus, Japan).

\section{Influence of ESC on Xenograft tumor models}

$3 \times 10^{6} \mathrm{HepG} 2$-luc cells were inoculated in nude mice subcutaneously to establish xenograft tumors which must be transplanted into nude mice for 3 generations. The tumor tissues in the growth period were cut into about $1.5 \mathrm{~mm}^{3}$ and were inoculated in the right armpit skin and liver of nude mice under the condition of sterile. 3-6 days after transplantation, the mice were divided into groups according to the tumor growth observed by in vivo imaging system. Every group contained 6 mice. Then the mice were injected intraperitoneally with ESC indifferent dose according to the MTD (maximum tolerant dosage) experiment. The sizes of subcutaneous tumors were measured with caliper and in vivo imaging and orthotopic tumors were observed by in vivo imaging. At the endpoint of the experiment, nude mice were sacrificed with cervical dislocation. The tumor samples were collected according to the follow-up experiments. The tumor growth inhibition rates and relative tumor volumes (RTV) were calculated, $\mathrm{RTV}=\mathrm{Vt} / \mathrm{V} 0$ ( Vt, the volumes of tumors of every calculation; V0, the volumes of tumors of initial administration).

miRNA expression profiles of cancer cells treated with ESC The experimental MHCC-97H cells were treated with the ESC (final concentration was $25 \mathrm{mg} / \mathrm{mL}$ ) for $24 \mathrm{~h}$. The control MHCC-97H cells were treated with vehicle agent for $24 \mathrm{~h}$. Total RNA of cells was isolated using trizol and purified with RNeasy mini kit (QIAGEN) according to manufacturer's instructions. RNA quality and quantity were measured by using nanodrop spectrophotometer (ND-1000, Nanodrop Technologies) and RNA integrity was determined by gel electrophoresis.

RNA labeling and array hybridization were according to Exiqon's manual. $1 \mu \mathrm{LRNA}$ in $2.0 \mu \mathrm{L}$ of water was combined with $1.0 \mu \mathrm{L}$ of CIP buffer and CIP (Exiqon). The mixture was incubated for $30 \mathrm{~min}$ at $37^{\circ} \mathrm{C}$. The reaction was terminated by incubation for $5 \mathrm{~min}$ at $95^{\circ} \mathrm{C}$. Then $3.0 \mu \mathrm{L}$ of labeling buffer, $1.5 \mu \mathrm{L}$ of fluorescent label (Hy3TM), $2.0 \mu \mathrm{L}$ of DMSO, $2.0 \mu \mathrm{L}$ of labeling enzyme were added into the mixture. The labeling reaction was incubated for $1 \mathrm{~h}$ at $16^{\circ} \mathrm{C}$. Terminated by incubation for $15 \mathrm{~min}$ at $65^{\circ} \mathrm{C}$. After stopping the labeling procedure, the $\mathrm{Hy} 3^{\mathrm{ma}}$-labeled samples were hybridized on the miRCURYTM LNA Array (v.18.0) (Exiqon) according to array manual. The total $25 \mu \mathrm{L}$ mixture from $\mathrm{Hy}^{\mathrm{rm}}$-labeled samples with $25 \mu \mathrm{L}$ hybridization buffer were first denatured for $2 \mathrm{~min}$ at $95^{\circ} \mathrm{C}$, incubated on ice for $2 \mathrm{~min}$. Then hybridized to the microarray for $16-20 \mathrm{~h}$ at $56{ }^{\circ} \mathrm{C}$ in a Hybridization Systems (Hybridization SystemNimblegen Systems, Inc., Madison, WI, USA). Following hybridization, the slides were achieved, washed several times using Wash buffer kit (Exiqon). Then the slides were scanned using the Axon GenePix 4000B microarray scanner (Axon Instruments, Foster City, CA).

\section{Evaluation of the expression level of miRNAs and target genes}

The expression level of miRNAs and target genes were measured and validated with real-time PCR. The methods were described as follows: $1.0 \mu \mathrm{g}$ RNA, $1 \mu \mathrm{L} 0.5 \mu \mathrm{g} / \mu \mathrm{LO}$ ligo (dT), $1.6 \mu \mathrm{L}$ DNTPs Mix (2.5 mM) and RNAase free water $10.9 \mu \mathrm{L}$ were made into annealing mixture.

The mixture was at $65^{\circ} \mathrm{C}$ for $5 \mathrm{~min}$ and on ice for $2 \mathrm{~min}$. After brief centrifugation, centrifugal pipe was added sequentially with RT mixture $(4 \mu \mathrm{L} 5 \mathrm{X}$ FirstStrand Buffer, $1 \mu \mathrm{L} 0.1 \mu \mathrm{M}$ DTT, $0.3 \mu \mathrm{L}$ RNase Inhibitor and $0.2 \mu \mathrm{L}$ SuperScript III RT).

Then the mixture was incubated at $37^{\circ} \mathrm{C}$ for $1 \mathrm{~min}$, at $50{ }^{\circ} \mathrm{C}$ for $1 \mathrm{~min}$, at $70^{\circ} \mathrm{C}$ for $15 \mathrm{~min}$, then the cDNAs were stored $-20^{\circ} \mathrm{C}$ to be used.

PCR Realtime reaction system contained $5 \mu \mathrm{L} 2 \times$ Master Mix, $0.5 \mu \mathrm{L} 10 \mu \mathrm{M}$ PCR forward primer, $0.5 \mu \mathrm{L} 10 \mu \mathrm{M}$ PCR Reverse primer and $4 \mu \mathrm{L} d \mathrm{dd}_{2} \mathrm{O}$. Primer sequences of validating genes were in Table 1.

After the reaction was mixed and centrifuged with $5000 \mathrm{rpm}, 8 \mu \mathrm{l}$ mixed solution was added into 384PCR plates, and then $2 \mu \mathrm{L}$ cDNA was added correspondingly. The reaction system was centrifuged briefly to mix. Three hundred eighty-four plates were placed on the PCR instrument (BIO-RAD) and all indicators were carried out according to the following 
Table 1

\begin{tabular}{|c|c|}
\hline Validating genes & Primer sequences \\
\hline \multirow[t]{2}{*}{ has-miR-638 } & F:5'-ATCCAGTGCGTGTCGTG-3' \\
\hline & R:5'-TGCTAGGGATCGCGGGCGGGTG-3' \\
\hline \multirow[t]{2}{*}{ has-miR-107 } & F:5'-ATACCGCTCGAGTGCCATGTGTCCACTGAAT-3' \\
\hline & R:5'-ATACCGCTCGAGTTCCATGCCTCAACTCCTCT-3' \\
\hline \multirow[t]{2}{*}{ has-miR-106-5p } & F:5'-GGGGGTAAAGTGCTGACAGT-3' \\
\hline & R:5'-GTGCGTGTCGTGGAGTCG-3' \\
\hline \multirow[t]{2}{*}{ U6 } & F:5'-GCTTCGGCAGCACATATACTAAAAT-3' \\
\hline & R:5'-CGCTTCACGAATTTGCGTGTCAT-3' \\
\hline \multirow[t]{2}{*}{ CDK2 } & F:5'-GTGGGCCCGGCAAGATTTTAG-3' \\
\hline & R:5'-GCCGAAATCCGCTTGTTAGGG-3' \\
\hline \multirow[t]{2}{*}{ sox2 } & F:5'-CACATGAAGGAGCACCCGGATTAT-3' \\
\hline & R:5'-GTTCATGTGCGCGTAACTGTCCAT-3' \\
\hline \multirow[t]{2}{*}{ STAT3 } & F:5'-TGGAAATAATGGTGAAGGTGC-3' \\
\hline & R:5'-ATCTGGGGTTTGGCTGTGT-3' \\
\hline \multirow[t]{2}{*}{$\mathrm{BCl} 2$} & F:5'-AGTGGGATGCGGGAGATGTG-3' \\
\hline & R:5'-GGGATGCGGCTGGATGGG-3' \\
\hline \multirow[t]{2}{*}{ Mcl1 } & F:5'-TAAGGACAAAACGGGACTGG-3' \\
\hline & R:5'-ACCAGCTCCTACTCCAGCAA-3' \\
\hline \multirow[t]{2}{*}{ CACNA2D1 } & F:5'-GACTGACCAACACCACTCTTCAC-3' \\
\hline & R:5'-CT ATCGTACCTCAGCTCCTTCC-3' \\
\hline \multirow[t]{2}{*}{ SALL4 } & F:5'-CCAAAGGCAACTTAAAGGTTCAC-3' \\
\hline & R:5'-CCGTGAAGACCAATGAGATCTCC-3' \\
\hline
\end{tabular}

procedures: $95^{\circ} \mathrm{C}, 10 \mathrm{~min} ; 40$ circles of $\operatorname{PCR}\left(95^{\circ} \mathrm{C}\right.$, $\left.10 \mathrm{~s} ; 60^{\circ} \mathrm{C}, 60 \mathrm{~s}\right)$. To establish the melting curve of PCR products, after amplified reaction was over, procedures were accorded as follows: ${ }^{\circ} \mathrm{C}, 10 \mathrm{~s} ; 60{ }^{\circ} \mathrm{C}, 60 \mathrm{~s} ; 95^{\circ} \mathrm{C}, 15 \mathrm{~s}$ and temperature was increased slowly from $60^{\circ} \mathrm{C}$ to $95^{\circ} \mathrm{C}\left(0.05^{\circ} \mathrm{C} / \mathrm{s}\right)$. The relative increase in reporter fluorescent dye emission was monitored. The level mRNA, relative to actin, was calculated using the formula: Relative mRNA expression $=2^{\wedge}$ [ct (validating genes $\left._{\text {control }}\right)$ - ct (validating genes $\left.\mathrm{ESC}_{\mathrm{ESC}}\right)+\mathrm{ct}\left(\mathrm{U} 6_{\mathrm{ESC}}\right)-$ ct $\left.\left(\mathrm{U} 6_{\text {control }}\right)\right]$, where ct is defined as the number of the cycle in which emission exceeds an arbitrarily defined threshold.

\section{Statistical analysis}

All data are the means of three determinations and data were analyzed using the SPSS Package for Windows (Version 16). Statistical analysis of the data was performed with ANOVA. Differences with $P<0.05$ were considered statistically significant.

\section{Results}

Growth inhibition of ESC in HepG2 cells and MHCC97H cells The inhibition rates of $25-125 \mu \mathrm{g} / \mathrm{mL}$ ESC at $24 \mathrm{~h}$ in HepG2 cells were respectively $-10.28 \%, 28.37 \%, 44.82 \%$, $54.63 \%, 61.33 \%$; the inhibition rates of $25-125 \mu \mathrm{g} / \mathrm{mL}$ ESC at $48 \mathrm{~h}$ HepG2 cells were respectively $15.62 \%, 48.59 \%$, $54.32 \%, 74.97 \%, 81.52 \%$; the inhibition rates of $25-125 \mu \mathrm{g} /$ $\mathrm{mL}$ ESC at $72 \mathrm{~h}$ HepG2 cells were respectively $16.16 \%, 61.89 \%, 74.32 \%, 84.09 \%, 88.23 \% \quad$ (Fig. 1a). $\quad$ IC50
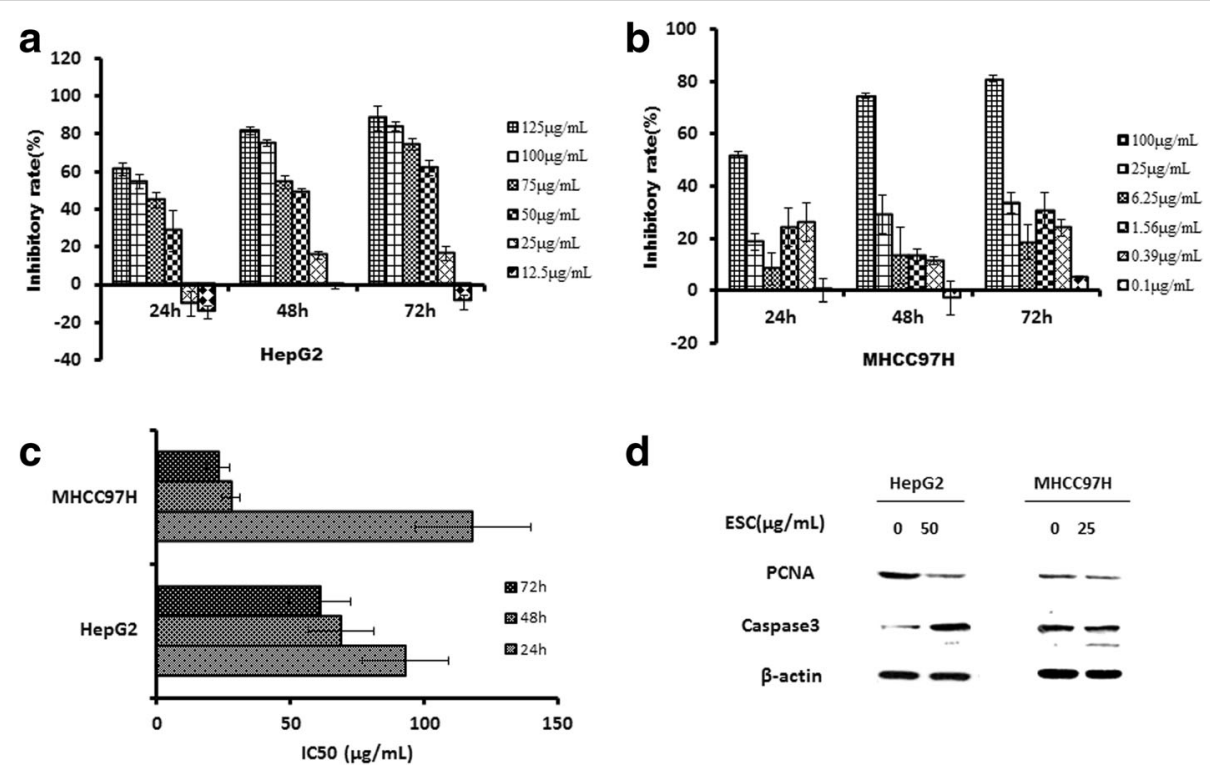

d

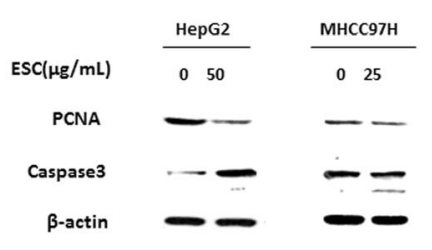

Fig. 1 Growth inhibition of ESC in HepG2 cells and MHCC97H cells. a Inhibition rates of ESC in HepG2 cells at 24, 48,72 h. b Inhibition rates of ESC in MHCC97H cells at 24, 48,72 h. c IC50 values of ESC in HepG2 and MHCC97H cells at 24, 48,72 h. $\mathbf{d}$ Influence of ESC on PCNA and caspases 3 expression in HepG2 cells and MHCC97H cells with western blot method 
values at 24,48,72 $\mathrm{h}$ were respectively 92.95, 68.96, $61.06 \mu \mathrm{g} / \mathrm{mL}$ (Fig. 1c). These results suggested 25-125 $\mu \mathrm{g} /$ $\mathrm{mL}$ ESC had a significant inhibitory effect on HepG2 cells and this effect showed a certain dose and time dependence. $50 \mu \mathrm{g} / \mathrm{mL}$ ESC can significantly inhibit of PCNA and increase Caspase 3 protein expression at $24 \mathrm{~h}$ in HepG2 cells (Fig. 1d). The inhibition rates of $0.39-125 \mu \mathrm{g} / \mathrm{mL}$ ESC at $24 \mathrm{~h}$ in MHCC97H cells were respectively $26.27 \%, 24.37 \%, 8.38 \%, 18.65 \%, 52.03 \%$; the inhibition rates of $0.39-125 \mu \mathrm{g} / \mathrm{mL}$ ESC at $48 \mathrm{~h}$ in MHCC $97 \mathrm{H}$ cells were respectively $11.39 \%, 13.63 \%, 13.50 \%$ ,29.06\%,74.30\%; the inhibition rates of $25-125 \mu \mathrm{g} / \mathrm{mL}$ ESC at $72 \mathrm{~h}$ in $\mathrm{MHCC} 97 \mathrm{H}$ cells were respectively $24.24 \%, 30.56 \%, 18.60 \%, 33.67 \%, 81.03 \%$ (Fig. 1b). IC50 values at $24,48,72 \mathrm{~h}$ were respectively $118.23,27.79$, $23.08 \mu \mathrm{g} / \mathrm{mL}$ (Fig. 1c). These results suggested $0.39-125 \mu \mathrm{g} / \mathrm{mL}$ ESC had a significant inhibitory effect on MHCC97H cells and this effect showed certain dose dependence. $25 \mu \mathrm{g} / \mathrm{mL}$ ESC can also slightly inhibit of PCNA and increase Caspase3 protein expression at $24 \mathrm{~h}$ in MHCC97H cells (Fig. 1d).

\section{EMT inhibition of ESC in HepG2 cells and MHCC97H cells} Immunofluorescence results showed that $50 \mu \mathrm{g} / \mathrm{mL}$ ESC can obviously reduce the expression of vimentin protein inHepG2 and $25 \mu \mathrm{g} / \mathrm{mLESC}$ can significantly upregulate E-cadherin protein expression in $\mathrm{MHCC} 97 \mathrm{H}$ cells (Fig. 2a). In MHCC97H, less than inhibitory concentration of $0.05 \mu \mathrm{g} / \mathrm{mL}$ ESC can inhibit obviously cell migration using transwell assay and the expression of vimentin with western blot method (Fig. $2 \mathrm{~b}$ and c). These results suggested that ESC can inhibit EMT in HepG2 cells and MHCC97H cells.
Growth and metastasis inhibition of ESC on xenograft models of HepG2 cells

Nude mice bearing tumors could be tolerated $2,4 \mathrm{mg} / \mathrm{kg}$ doses of ESC, and the weight loss was always less than $20 \%$ during the whole experiment. $2,4 \mathrm{mg} / \mathrm{kg}$ ESC could significantly inhibit the relative tumor volume of subcutaneous xenograft hepatocellular carcinoma (Fig. 3a). In vivo imaging showed that $2,4 \mathrm{mg} / \mathrm{kg}$ ESC significantly inhibited fluorescence density value of tumor interior. Tumor growth inhibition rates of $2,4 \mathrm{mg} / \mathrm{kg}$ ESC were respectively $43.01 \%$ and $32.49 \%$. Fluorescence reduction rates of $2,4 \mathrm{mg} / \mathrm{kg}$ ESC were respectively $22.29 \%$ and $14.03 \%$ (Fig. 3b). $2 \mathrm{mg} / \mathrm{kg}$ ESC could also significantly inhibit fluorescence density value of tumor interior in orthotopic xenograft nude mice and inhibited intrahepatic metastasis rate. Intrahepatic metastasis rates of control and $2 \mathrm{mg} / \mathrm{kg}$ ESC groups were respectively 67\% and $16.67 \%$. Fluorescence reduction rate of $2 \mathrm{mg} / \mathrm{kg}$ ESC was $49.30 \%$ (Fig. 3c). Pathological tissue showed severe necrosis in tumor tissues of subcutaneous xenograft nude mice and infiltration by inflammatory cells in orthotopic tumor tissues after treatment with ESC (Fig. 3d). These results suggested that ESC could inhibit the growth and metastasis of hepatocellular carcinoma.

\section{miRNA expression profiles of HCC cells treated with ESC} RNAs ofMHCC $97 \mathrm{H}$ cells were extracted to screen differential miRNAs after being treated with $25 \mu \mathrm{g} / \mathrm{mL}$ ESC. 35 up-regulated and 34 down-regulated miRNAs were detected in total of 429 miRNAs in accordance with the standard (fluorescence value change> 1.5 times and have significant difference between ESC and control group) (Fig. 4a). Among of them, 12miRNAs (hsa-miR-139-5p,

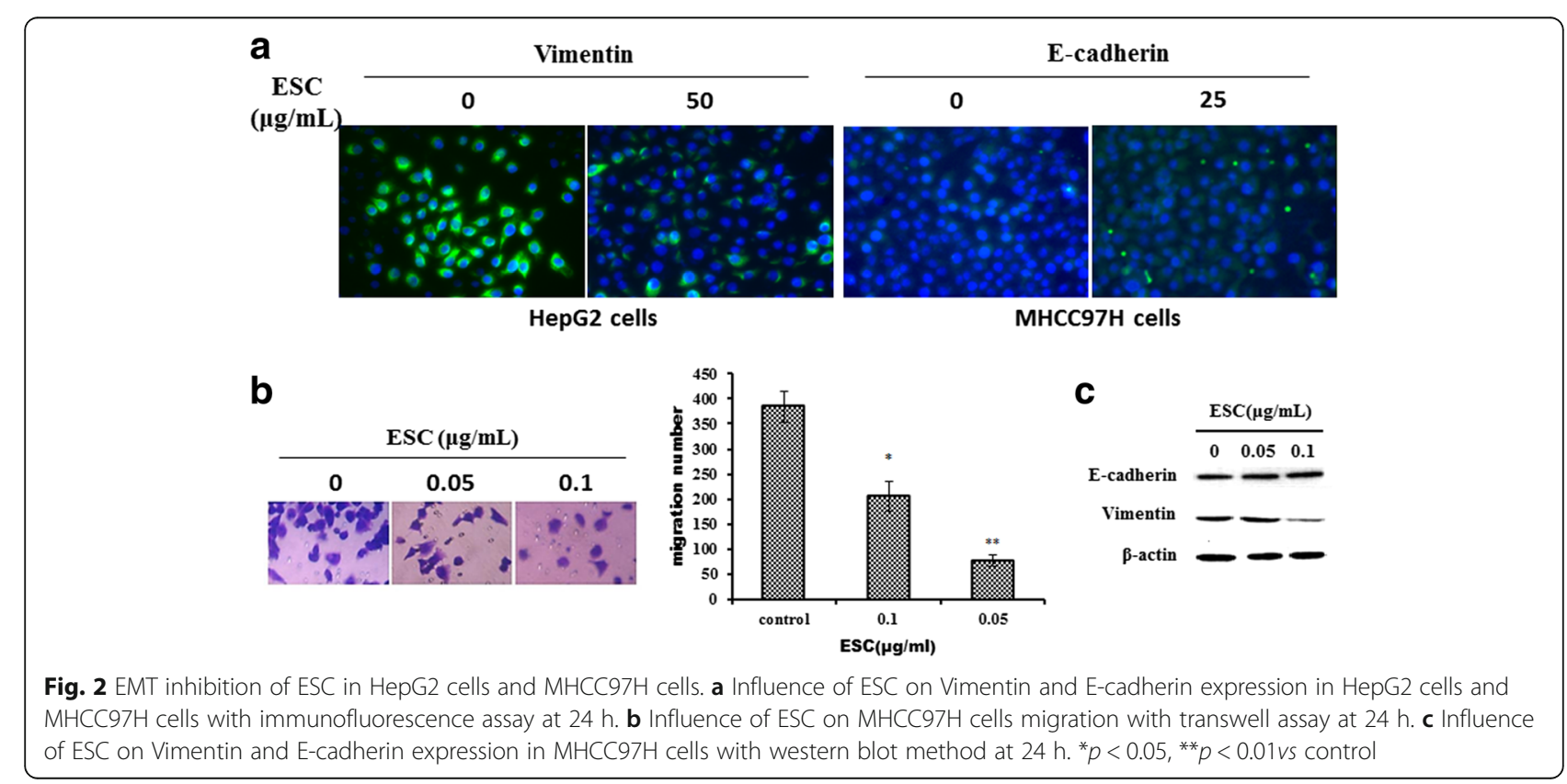


a

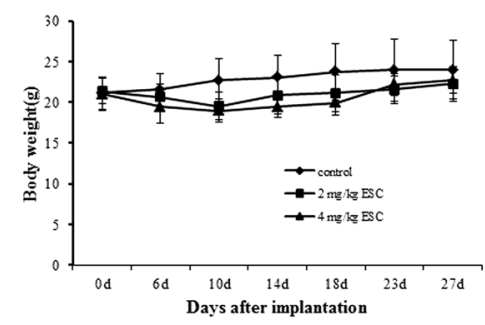

b

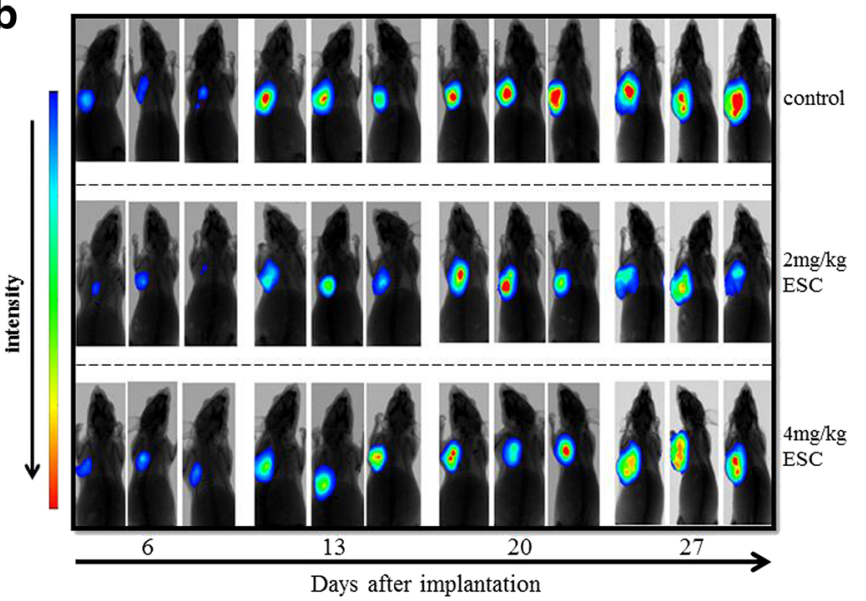

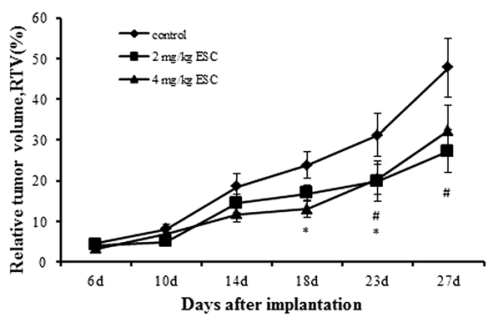
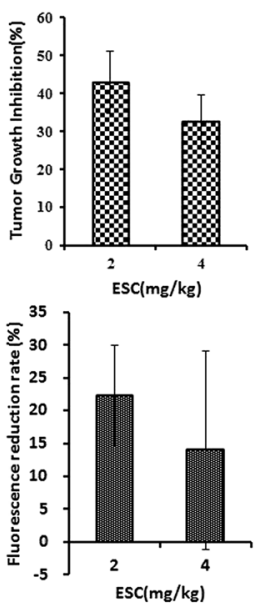

C
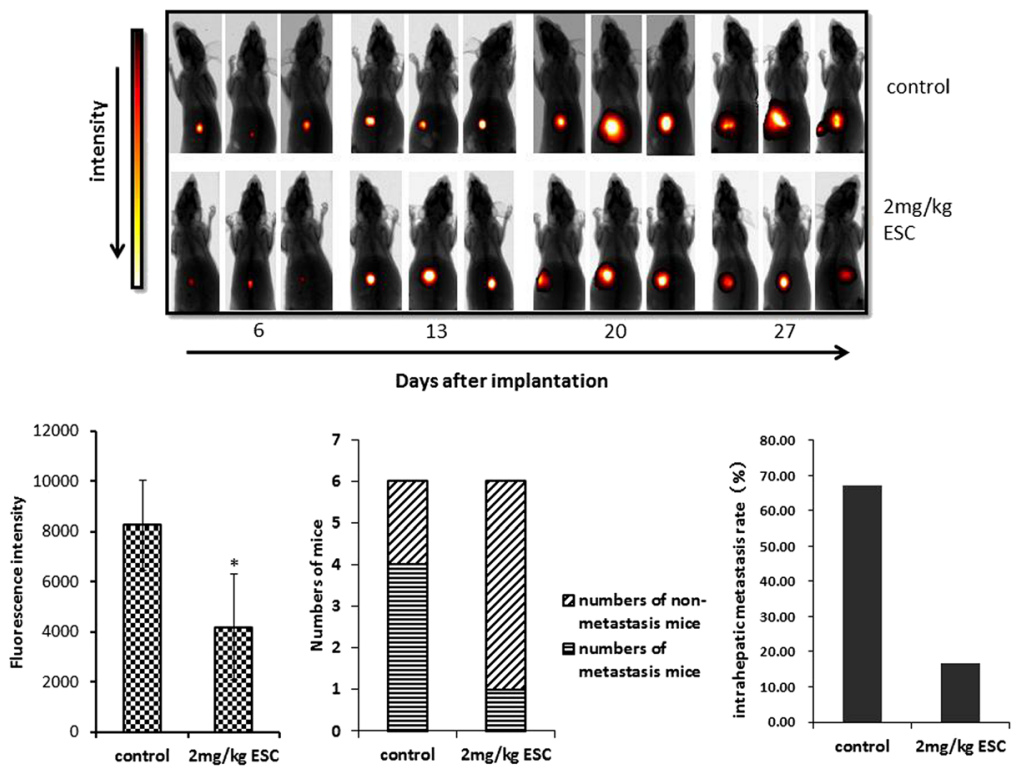

d subcutaneous xenograft Orthotopic xenograft
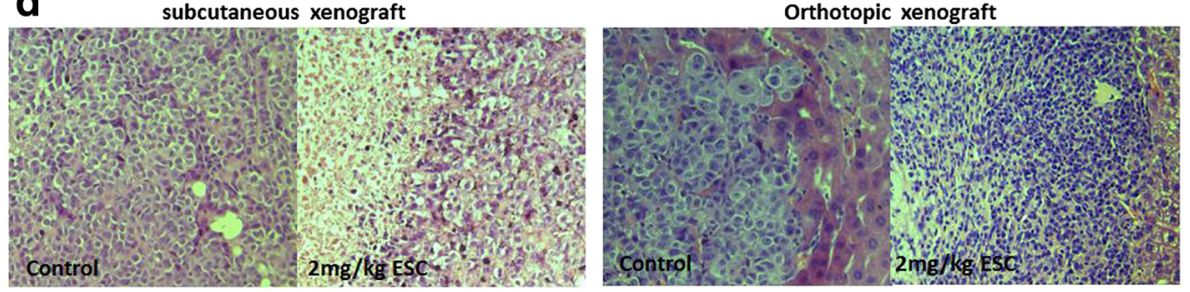
(See figure on previous page.)

Fig. 3 Growth and metastasis inhibition of ESC on xenograft tumor models mice of HepG2 cells. a Changes of body weight and RTV of subcutaneous xenograft model mice of HepG2cells after treated with ESC. $\mathbf{b}$ Influence of ESC on subcutaneous xenograft tumor models mice of HepG2 cells by in vivo imaging. $\mathbf{c}$ Influence of ESC on orthotopic xenograft tumor models mice of HepG2 cells by in vivo imaging. $\mathbf{d}$ Hemetoxylin and Eosin Stains of xenograft tumor tissues $(\times 100)$

hsa-miR-638, hsa-miR-107, hsa-miR-331-3p, hsa-miR21-3p, hsa-miR-134-5p, hsa-miR-16-1-3p, hsa-miR-3395p, hsa-miR-106b-5p, hsa-miR-423-3p, hsa-miR-491-3p, hsa-miR-24-3p) were related to cancers. According to the professional knowledge and literature (Table 2), 3 differential miRNAs (hsa-miR-107, hsa-miR-638, hsa-
miR-106b-5p) that related to cancers were singled out for real-time PCR validation. Real-time PCR results showed that hsa-miR-107, hsa-miR-638 expressions were obviously different in MHCC97H cells and the difference of hsa-miR-107 in the HepG2 cells was obviously observed (Fig. 4b).
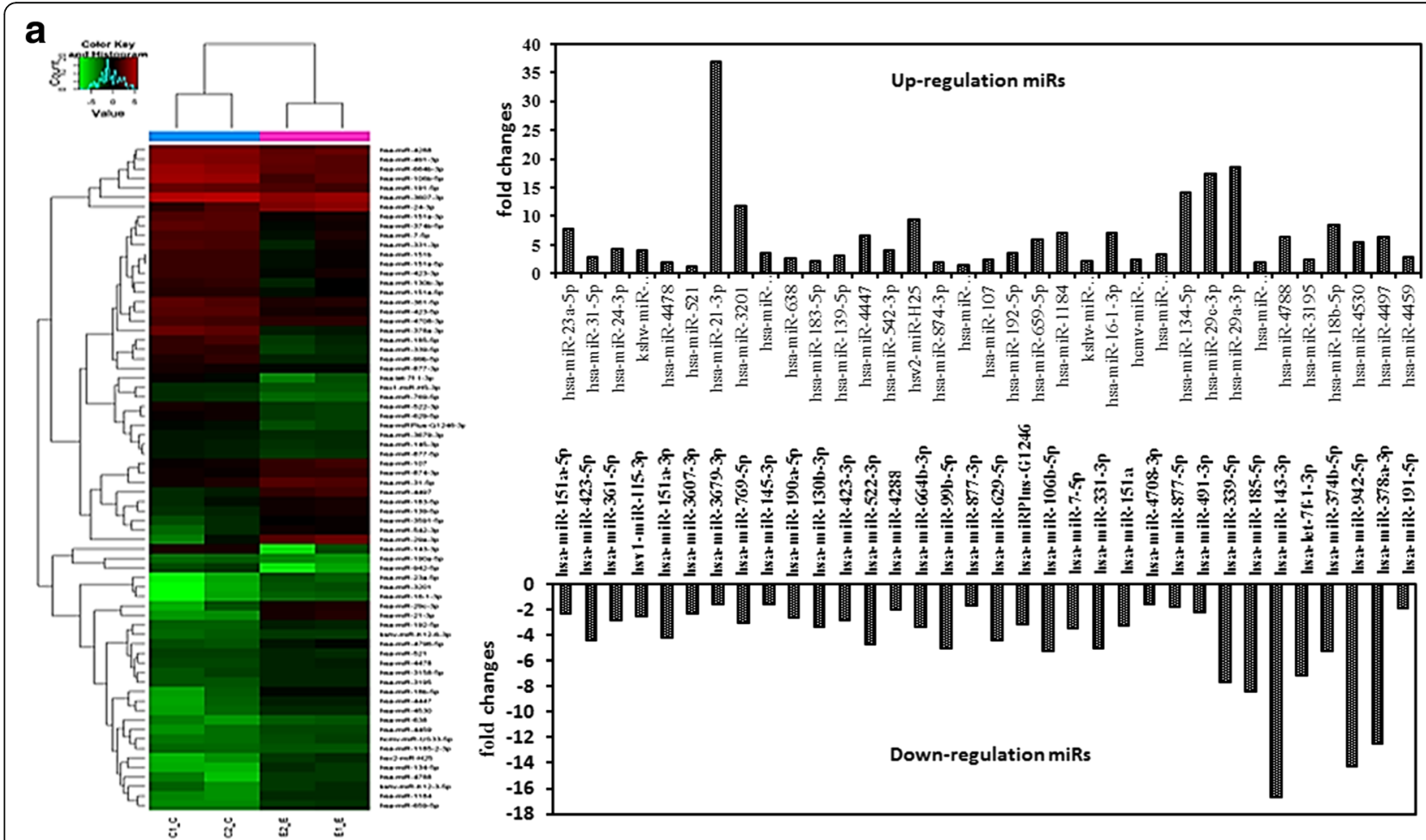

b
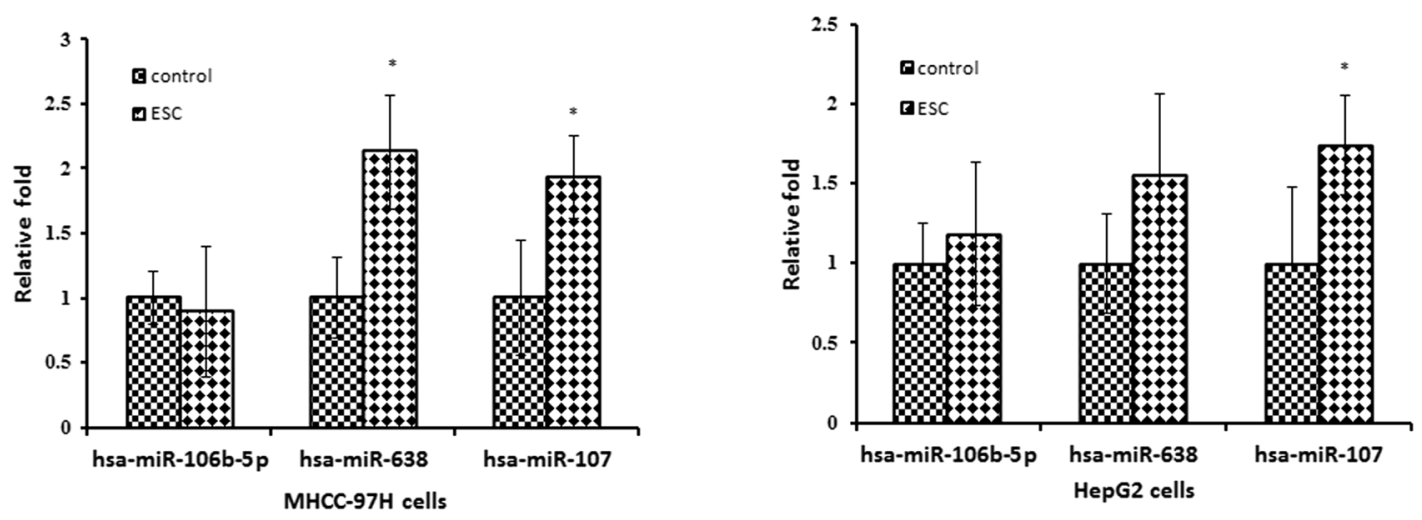

Fig. 4 miRNA expression profiles of HCC cells treated with ESC. a Profile of miRNAs of MHCC97H cells treated with ESC. b Part differential miRNA expressions were verified with realtime PCR in MHCC97H and HepG2 cells. ${ }^{*} p<0.05,{ }^{* *} p<0.01$ vs control 
Table 2 Part differential miRNAs involving with cancers

\begin{tabular}{|c|c|c|c|c|}
\hline miRNAs & $\begin{array}{l}\text { Fold } \\
\text { change }\end{array}$ & $P$-value & $\begin{array}{l}\text { miRNA related } \\
\text { to cancers }\end{array}$ & References \\
\hline \multirow[t]{8}{*}{ has-miR-638 } & \multirow[t]{8}{*}{2.97} & \multirow[t]{8}{*}{0.02} & $\begin{array}{l}\text { Non-small cell lung } \\
\text { cancer }\end{array}$ & [24-26] \\
\hline & & & Melanoma & {$[27]$} \\
\hline & & & Leukemia & {$[28]$} \\
\hline & & & Hepatocellular cancer & {$[29]$} \\
\hline & & & Colorectal carcinoma & {$[29-32,15]$} \\
\hline & & & Breast cancer & {$[33]$} \\
\hline & & & Gastric cancer & {$[34]$} \\
\hline & & & Cervical cancer & {$[35]$} \\
\hline \multirow[t]{7}{*}{ has-miR-107 } & \multirow[t]{7}{*}{2.56} & \multirow[t]{7}{*}{0.04} & Gastric adenocarcinoma & {$[36,37]$} \\
\hline & & & Glioma & {$[38,39]$} \\
\hline & & & $\begin{array}{l}\text { Non-small cell lung } \\
\text { cancer }\end{array}$ & {$[40]$} \\
\hline & & & Cervical cancer & {$[14]$} \\
\hline & & & Leukemia & {$[41]$} \\
\hline & & & Colorectal cancer & {$[42]$} \\
\hline & & & $\begin{array}{l}\text { Neck squamous cell } \\
\text { carcinoma }\end{array}$ & {$[15]$} \\
\hline \multirow[t]{5}{*}{ has-miR-106-5p } & \multirow[t]{5}{*}{0.19} & \multirow[t]{5}{*}{0.03} & Pancreatic cancer & {$[43]$} \\
\hline & & & Renal carcinoma & {$[44]$} \\
\hline & & & Glioma & {$[45]$} \\
\hline & & & Colorectal cancer & [13] \\
\hline & & & Breast cancer & {$[46]$} \\
\hline
\end{tabular}

\section{Evaluation of the expression level of target genes}

According to the bioinformatics prediction and references (Table 3), we chose target genes STAT3, CACNA2D1, SALL4, MCL1, CDK2, SOX2 and Bcl2 for real-time PCR validation. The results showed that ESC could significantly down regulate SALL4, McL-1 and Bcl-2 genes in HCC cells (Fig. 5).

Table 3 Target genes of different miRNAs

\begin{tabular}{llll}
\hline iniRNAs & $\begin{array}{l}\text { Target } \\
\text { genes }\end{array}$ & $\begin{array}{l}\text { Databases of bioinformatics } \\
\text { prediction }\end{array}$ & References \\
\hline has-miR-638 & CDK2 & & {$[24-26]$} \\
& SOX2 & & {$[27]$} \\
has-miR-106-5p & STAT3 & $\begin{array}{l}\text { Miranda; mirbase; } \\
\text { targetscan }\end{array}$ & {$[36,37,47]$} \\
has-miR-107 & MCL1 & miranda; mirbase; & {$[40]$} \\
& CACNA2D1 & $\begin{array}{l}\text { targetscan } \\
\text { Miranda; mirbase; }\end{array}$ & {$[14]$} \\
& SALL4 & targetscan & {$[41]$} \\
\hline
\end{tabular}

\section{Discussion}

In this study, ESC showed promising inhibitory effect on growth of HepG2 and MHCC97H cells in dose and time dependent style. MHCC97H cells were more sensitive to ESC. ESC also obviously inhibited apoptotic protein caspase 3 and proliferative protein PCNA in these two cell lines. ESC inhibited EMT protein vimentin in HepG2 cells and upregulated E-cadherin in MHCC97H cells. ESC of low concentration might regress the migration of $\mathrm{MHCC} 97 \mathrm{H}$ cells and inhibit EMT protein vimentin expression. Interestingly, the lowest dose $(0.05 \mu \mathrm{g} / \mathrm{mL})$ of ESC inhibited the cell migration more effectively than the highest dose $(0.1 \mu \mathrm{g} / \mathrm{mL})$. However, $0.1 \mu \mathrm{g} / \mathrm{mL}$ of ESC was more effective to increase the expression of E-cadherin and decrease that of vimentin. The contradiction result may be related to the complexity of the ESC components. No matter how, these results suggested that ESC could inhibit proliferation and EMT in HCC cells in vitro. In vivo results showed that ESC significantly inhibited tumor growth in either subcutaneous or orthotopic xenograft models mice of HepG2. ESC also had certain inhibitory effect on intrahepatic metastasis. All these results suggested that ESC was an important potential inhibitor of hepatocellular carcinoma.

Plenty of studies have shown that miRNAs play fundamental roles in many pathological processes. Meanwhile accumulating evidences in cancer diagnostics and therapeutics indicate that miRNAs involve in HCC progression, which may serve as either sensitive biomarkers for detecting carcinogenesis as well as monitoring therapies of HCC or tumor suppressors or oncogenes [10-12]. As we all know, Traditional Chinese Medicine (TCM) has the characteristics of multiple effective targets on the diseases and we reasonably hypothesized that ESC might exert anti-tumor role by regulating microRNAs. Here, the anti-cancer mechanisms of ESC targeting miRNAs have been extensively explored, and we chose miRNA array to detect the miRNA profile of $\mathrm{MHCC} 97 \mathrm{H}$ cells treated with ESC. 69 differential miRNAs in total of 429 ones were obtained. According to the references, we selected hsa-miR-107, hsa-miR-638, hsa-miR-106b-5p to be verified with real-time PCR in $\mathrm{MHCC} 97 \mathrm{H}$ and HepG2 cells. Expressions of hsa-miR-107, hsa-miR638 in HCC cells treated by ESC were significantly increased. Hsa-miR-107, which functionally overlaps with miR-15, miR-16, and miR-195 due to a common 5 ' sequence critical for target specificity [13]. There were opposite arguments in roles of hsa-miR-107 on cancers. Hsa-miR-107 activated ATR/Chk1 pathway, suppressed cervical cancer invasion and inhibited the tumorigenicity of head and neck squamous cell carcinoma $[14,15]$. hsa-miR-107 is also confirmed to 


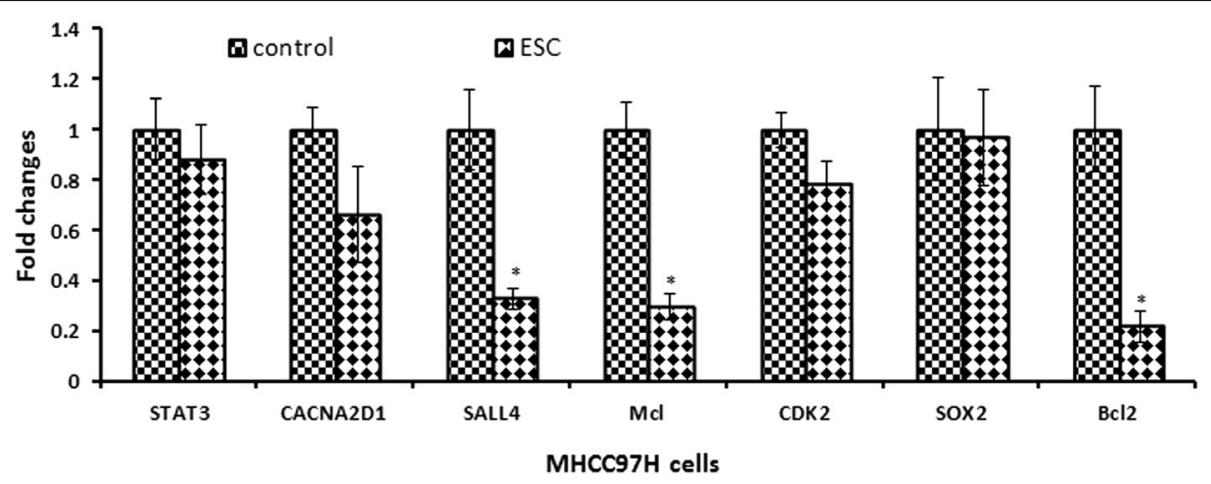

Fig. 5 Evaluation of the expression level of target genes. Target genes STAT3, CACNA2D1, SALL4, MCL1, CDK2, SOX2 and BCI2 of miRNAs were validated with real-time PCR in MHCC-97H cells. ESC could significantly downregulate SALL4, MCL-1 and BCl-2 genes that has-miR-107 targeted in MHCC-97H cells. ${ }^{*} p<0.05,{ }^{* *} p<0.01$ vs control

be involved in the progression of $\mathrm{HCC}[12,16]$. In this study, we found ESC could upregulate the expression hsa-miR-107 in both MHCC97H and HepG2 cells. Increased expression of hsa-miR-638 was only observed in MHCC97H cells treated by ESC, while the expression of hsa-miR-106b-5p did not change in any of these two cancer cell lines. These results confirmed that ESC could inhibit hepatocellular carcinoma by regulating some miRNAs.

Correspondingly, the target genes of hsa-miR-107, hsa-miR-638, hsa-miR-106b-5p were measured with PCR assay. Interestingly, only target genes of hsa-miR107 were changed greatly. From the references and databases of bioinformatics, we have known that MCL1, CACNA2D1, SALL4 and Bcl2 were target genes of hsamiR-107. Discovered as crucial modulators of apoptosis, anti-apoptotic $\mathrm{Bcl}-2$ protein family emerged more recently as important modulators of other essential cancer processes, including cell cycle, autophagy or cell metabolism. Most cancer cell models overexpress one or more of the three major proteins: BCL-2 (B-cell lymphoma 2), BCL-xL (B-cell lymphoma-extra-large) and MCL1 (myeloid cell leukemia1). MCL1 and BCL-2 could enhance cell survival by inhibiting apoptosis [17, 18]. CACNA2D1(calcium voltage-gated channel auxiliary subunit alpha2delta 1) genes was critical for HCC TIC (tumor initiating cell) stemness and was predictive of poor prognosis for HCC patients [19, 20]. SALL4 (spalt like transcription factor 4), a member of a family of zinc finger transcription factors, was a marker for a progenitor subclass of HCC with an aggressive phenotype and a regulator of embryogenesis, organogenesis, pluripotency. Upregulation of SALL4 was also associated with poor prognosis in HCC [21-23]. The real-time PCR validation showed that ESC downregulated the MCL1, SALL4 and BCL2 gene expression significantly, but did not influence the expression of CACNA2D1. These results illustrated that ESC might regulate target genes of miRNAs, but what regulating style, direct or indirect, was still needed to be further explored in future.

\section{Conclusion}

ESC regressed growth and metastasis of human hepatocellular carcinoma. ESC obviously upregulated hsa-miR-107 and hsa-miR-638 expression, but only target genes of hsa-miR-107, MCL1, SALL4 and Bcl2, were changed greatly. These findings suggested that regulating microRNAs expression and their corresponding target genes might the one of important molecular mechanisms of ESC treatment with HCC.

\section{Abbreviations}

BCL2: B-cell lymphoma 2; CACNA2D1: Calcium voltage-gated channel auxiliary subunit alpha2 delta 1; CDK2: Cyclin-dependent kinase 2; DMSO: Dimethyl sulfoxide; EMT: Epithelial mesenchymal transition;

ESC: Extract of Stellerachamaejasme; HCC: Hepatocellular carcinoma; IC50: Half-maximal inhibitory concentration; IR: Inhibition rate; IVC: Individually ventilated cage; MCL1: Myeloid cell leukemia-1; MTT: 3-(4,5dimethyl- 2-thiazolyl)-2,5-diphenyl-2-H-tetrazolium bromide; PCR: Polymeras chain reaction; RT: Reverse transcription; RTV: Relative tumor volume;

SALL1: Spalt like transcription factor 4; SOX2: Sex determining region Y box 2; STAT: Signal transducers and activators of transcription;

TGF: Transforming growth factor; TIC: Tumor initiating cell

\section{Funding}

This work was supported by National Major Scientific and Technological Special Project for "Significant New Drugs Development"during the Twelfth Five-year Plan Period (No. 2013ZX09301307001004), Training plan for high level of health technical personnel of Beijing health system (2015-3-101), Foundation of Beijing Institute of Hepatology(No. BJIH-01604)and National Natural Science Foundation of China (No. 81303273), Beijing Municipal Institute of Public Medical Research Development and Reform Pilot Project (No. 2016-2) and Beijing Precision Medicine and Transformation Engineering Technology Research Center of Hepatitis and Liver Cancer.

Availability of data and materials

The data are included in the article as figures and tables.

\section{Authors' contributions}

$X \mathrm{~L}$ was the main experimental investigator and designer. $\mathrm{XL}$ had drafted the manuscript. SW carried out the cell culture. JX and BK participated the animal experiments. DC helped to complete the molecular experiments. YW helped to analyze the data. XZ supervised the study and the manuscript. All authors read and approved the final manuscript. 


\section{Ethics approval}

All studies involving animals were conducted according to the welfare and ethical guidelines for experimental animal drafted by Beijing Experimental Animal Management Office and approved by Committee for Control and Supervision of Experiments on Animals of Capital Medical University.

\section{Consent for publication}

Not applicable

\section{Competing interests}

The authors declared no potential conflicts of interest with respect to the research, authorship, and/or publication of this article.

\section{Publisher's Note}

Springer Nature remains neutral with regard to jurisdictional claims in published maps and institutional affiliations.

\section{Author details}

'Beijing Institute of Hepatology and Beijing YouAn Hospital, Capital Medical University, No 8 Xi TouTiao, You An Men Wai, Feng Tai Qu, Beijing 100069, China. ${ }^{2}$ Institute of Chinese Materia Medica, China Academy of Chinese Medical Sciences, No 16 Nan Xiao Jie, Dong Zhi Men Nei, Dong Cheng Qu, Beijing 100700, China.

\section{Received: 7 September 2017 Accepted: 1 February 2018}

Published online: 20 March 2018

\section{References}

1. Bartel DP. MicroRNAs: target recognition and regulatory functions. Cell. 2009;136(2):215-33.

2. Wang $L, Y u e ~ Y$, Wang $X$, Jin $H$. Function and clinical potential of microRNAs in hepatocellular carcinoma. Oncol Lett. 2015;10(6):3345-53.

3. Laudadio L, Manfroid I, Achouri Y, Schmidt D, Wilson MD, Cordi S, Thorrez L, Knoops L, Jacquemin P, Schuit F, Pierreux CE, Odom DT, Peers B, Lemaigre FP. A feedback loop between the liver-enriched transcription factor network and miR-122 controls hepatocyte differentiation. Gastroenterology. 2012; 142(1):119-29.

4. Chai ZT, Kong J, Zhu XD, Zhang YY, Lu L, Zhou JM, Wang LR, Zhang KZ, Zhang QB, Ao JY, Wang M, Wu WZ, Wang L, Tang ZY, Sun HC. MicroRNA-26a inhibits angiogenesis by down-regulating VEGFA through the PIK3C2a/Akt/HIF-1a pathway in hepatocellular carcinoma. PLoS One. 2013;8(10):e77957.

5. Yang H, Cho ME, Li TW, Peng H, Ko KS, Mato JM, Lu SC. MicroRNAs regulate methionine adenosyltransferase 1A expression in hepatocellular carcinoma. J Clin Invest. 2013:123(1):285-98.

6. Zhang Y, Yang P, Wang XF. Microenvironmental regulation of cancer metastasis by miRNAs. Trends Cell Biol. 2014:24(3):153-60.

7. Liu X, Yang Q, Zhang G, Li Y, Chen Y, Weng X, Wang Y, Wang Y, Zhu X. Anti-tumor pharmacological evaluation of extracts from stellerachamaejasme L based on hollow fiber assay. BMC Complement Altern Med. 2014;14:116.

8. Liu XN, Wang S, Yang Q, Wang YJ, Chen DX, Zhu XX. ESC reverses epithelial mesenchymal transition induced by transforming growth factor- $\beta$ via inhibition of Smad signal pathway in HepG2 liver cancer cells. Cancer Cell Int. 2015;15:114

9. Liu X, Yang Q, Zhang G, Li Y, Chen Y, Weng X, Wang Y, Wang Y, Zhu X. Antitumor pharmacological evaluation of extracts from stellerachamaejasme $L$ based on hollow fiber assay. BMC Complement Altern Med. 2014;14(1):116

10. Hong M, Wang N, Tan HY, Tsao SW, Feng Y. MicroRNAs and Chinese medicinal herbs: new possibilities in cancer therapy. Cancers (Basel). 2015;7(3):1643-57.

11. Yang N, Ekanem NR, Sakyi CA, Ray SD. Hepatocellular carcinoma and microRNA: new perspectives on therapeutics and diagnostics. Adv Drug Deliv Rev. 2015:81:62-74

12. Mao B, Wang G. MicroRNAs involved with hepatocellular carcinoma (review). Oncol Rep. 2015;34(6):2811-20

13. Zheng L, Zhang Y, Liu Y, Zhou M, Lu Y, Yuan L, Zhang C, Hong M, Wang S, $\mathrm{Li} X$. MiR-106b induces cell radioresistance via the PTEN/PI3K/AKT pathways and p21 in colorectal cancer. J Transl Med. 2015:13.252.

14. Zhou C, Li G, Zhou J, Han N, Liu Z, Yin J. miR-107 activates ATR/Chk1 pathway and suppress cervical cancer invasion by targeting MCL1. PLoS One. 2014;9(11):e111860
15. Piao L, Zhang M, Datta J, Xie X, Su T, Li H, Teknos TN, Pan Q. Lipid-based nanoparticle delivery of pre-miR-107 inhibits the tumorigenicity of head and neck squamous cell carcinoma. Mol Ther. 2012;20(6):1261-9.

16. Zhang JJ, Wang CY, Hua L, Yao KH, Chen JT, Hu JH. miR-107 promotes hepatocellular carcinoma cell proliferation by targeting Axin2. Int J Clin Exp Pathol. 2015;8(5):5168-74.

17. Hardwick JM, Soane L. Multiple functions of BCL-2 family proteins. Cold Spring Harb Perspect Biol. 2013;5(2):a008722.

18. Cerella C, Muller F, Gaigneaux A, Radogna F, Viry E, Chateauvieux S, Dicato M, Diederich M. Early downregulation of $\mathrm{Mcl}-1$ regulates apoptosis triggered by cardiac glycoside UNBS1450. Cell Death Dis. 2015;6:e1782.

19. Zhao W, Wang L, Han H, Jin K, Lin N, Guo T, Chen Y, Cheng H, Lu F, Fang W, Wang $Y$, Xing B, Zhang Z. 1B50-1, a mAb raised against recurrent tumor cells, targets liver tumor-initiating cells by binding to the calcium channel a2 $\delta 1$ subunit. Cancer Cell. 2013:23(4):541-56.

20. Han H, Du Y, Zhao W, Li S, Chen D, Zhang J, Liu J, Suo Z, Bian X, Xing B, Zhang Z. PBX3 is targeted by multiple miRNAs and is essential for liver tumour-initiating cells. Nat Commun. 2015;6:8271.

21. Tanaka Y, Aishima S, Kohashi K, Okumura Y, Wang H, Hida T, Kotoh K, Shirabe K, Maehara Y, Takayanagi R, Oda Y. Spalt-like transcription factor 4 immunopositivity is associated with epithelial cell adhesion molecule expression in combined hepatocellular carcinoma and cholangiocarcinoma. Histopathology. 2016;68(5):693-701.

22. Han SX, Wang JL, Guo XJ, He CC, Ying X, Ma JL, Zhang YY, Zhao Q, Zhu Q. Serum SALL4 is a novel prognosis biomarker with tumor recurrence and poor survival of patients in hepatocellular carcinoma. J Immunol Res. 2014;2014:262385.

23. Oikawa T, Kamiya A, Zeniya M, Chikada H, Hyuck AD, Yamazaki Y, Wauthier E, Tajiri H, Miller LD, Wang XW, Reid LM, Nakauchi H. Sal-like protein 4 (SALL4), a stem cell biomarker in liver cancers. Hepatology. 2013;57(4):1469-83.

24. Wang F, Lou JF, Cao Y, Shi XH, Wang P, Xu J, Xie EF, Xu T, Sun RH, Rao JY, Huang PW, Pan SY, Wang H. miR-638 is a new biomarker for outcome prediction of non-small cell lung cancer patients receiving chemotherapy. ExpMol Med. 2015;8(47):e162.

25. Xia Y, Wu Y, Liu B, Wang P, Chen Y. Downregulation of miR-638 promotes invasion and proliferation by regulating SOX2 and induces EMT in NSCLC. FEBS Lett. 2014:588(14):2238-45.

26. Wang WX, Kyprianou N, Wang X, Nelson PT. Dysregulation of the mitogen granulin in human cancer through the miR-15/107 microRNA gene group. Cancer Res. 2010;70(22):9137-42.

27. Bhattacharya A, Schmitz U, Raatz $Y$, Schönherr M, Kottek T, Schauer M, Franz S, Saalbach A, Anderegg U, Wolkenhauer O, Schadendorf D, Simon JC, Magin T, Vera J, Kunz M. miR-638 promotes melanoma metastasis and protects melanoma cells from apoptosis and autophagy. Oncotarget. 2015; 6(5):2966-80.

28. Lin Y, Li D, Liang Q, Liu S, Zuo X, Li L, Sun X, Li W, Guo M, Huang Z. miR638 regulates differentiation and proliferation in leukemic cells by targeting cyclin-dependent kinase 2. J Biol Chem. 2015:290(3):1818-28.

29. Kubota S, Chiba M, Watanabe M, Sakamoto M, Watanabe N. Secretion of small/microRNAs including miR-638 into extracellular spaces by sphingomyelin phosphodiesterase 3. Oncol Rep. 2015;33(1):67-73.

30. Zhang J, Fei B, Wang Q, Song M, Yin Y, Zhang B, Ni S, Guo W, Bian Z, Quan C, Liu Z, Wang Y, Yu J, Du X, Hua D, Huang Z. MicroRNA-638 inhibits cell proliferation, invasion and regulates cell cycle by targeting tetraspanin 1 in human colorectal carcinoma. Oncotarget. 2014;5(23):12083-96.

31. Tay Y, Tan SM, Karreth FA, Lieberman J, Pandolfi PP. Characterization of dual PTEN and p53-targeting microRNAs identifies microRNA-638/Dnm2 as a two-hit oncogenic locus. Cell Rep. 2014;8(3):714-22.

32. Ma K, Pan X, Fan P, He Y, Gu J, Wang W, Zhang T, Li Z, Luo X. Loss of miR-638 in vitro promotes cell invasion and a mesenchymal-like transition by influencing SOX2 expression in colorectal carcinoma cells. Mol Cancer. 2014;13:118.

33. Tan X, Peng J, Fu Y, An S, Rezaei K, Tabbara S, Teal CB, Man YG, Brem RF, Fu SW. miR-638 mediated regulation of BRCA1 affects DNA repair and sensitivity to UV and cisplatin in triple-negative breast cancer. Breast Cancer Res. 2014;16(5):435.

34. Zhao LY, Yao Y, Han J, Yang J, Wang XF, Tong DD, Song TS, Huang C, Shao Y. miR-638 suppresses cell proliferation in gastric cancer by targeting Sp2. Dig Dis Sci. 2014;59(8):1743-53

35. Wilting SM, Verlaat W, Jaspers A, Makazaji NA, Agami R, Meijer CJ, Snijders PJ, Steenbergen RD. Methylation-mediated transcriptional repression of microRNAs during cervical carcinogenesis. Epigenetics. 2013:8(2):220-8. 
36. Zhang M, Wang X, Li W, Cui Y. miR-107 and miR-25 simultaneously target LATS2 and regulate proliferation and invasion of gastric adenocarcinoma (GAC) cells. Biochem Biophys Res Commun. 2015;460(3):806-12.

37. Wang $S$, Lv C, Jin H, Xu M, Kang M, Chu H, Tong N, Wu D, Zhu H, Gong W, Zhao Q, Tao G, Zhou J, Zhang Z, Wang M. A common genetic variation in the promoter of miR-107 is associated with gastric adenocarcinoma susceptibility and survival. Mutat Res. 2014;769:35-41.

38. Ji Y, Wei Y, Wang J, Ao Q, Gong K, Zuo H. Decreased expression of microRNA107 predicts poorer prognosis in glioma. Tumour Biol. 2015;36(6):4461-6.

39. He J, Zhang W, Zhou Q, Zhao T, Song Y, Chai L, Li Y. Low-expression of microRNA-107 inhibits cell apoptosis in glioma by upregulation of SALL4. Int J Biochem Cell Biol. 2013;45(9):1962-73.

40. Zhang Z, Zhang L, Yin ZY, Fan XL, Hu B, Wang LQ, Zhang D. miR-107 regulates cisplatin chemosensitivity of A549 non small cell lung cancer cell line by targeting cyclin dependent kinase. Int J Clin Exp Pathol. 2014;7(10):7236-41.

41. Ruan J, Liu X, Xiong X, Zhang C, Li J, Zheng H, Huang C, Shi Q, Weng Y. miR-107 promotes the erythroid differentiation of leukemia cells via the downregulation of Cacna2d1. Mol Med Rep. 2015;11(2):1334-9.

42. Molina-Pinelo S, Carnero A, Rivera F, Estevez-Garcia P, Bozada JM, Limon ML, Benavent M, Gomez J, Pastor MD, Chaves M, Suarez R, Paz-Ares L, de la Portilla F, Carranza-Carranza A, Sevilla I, Vicioso L, Garcia-Carbonero R. MiR107 and miR-99a-3p predict chemotherapy response in patients with advanced colorectal cancer. BMC Cancer. 2014;14:656.

43. Luo ZL, Luo HJ, Fang C, Cheng L, Huang Z, Dai R, Li K, Tian FZ, Wang $T$, Tang $L$. Negative correlation of ITCH E3 ubiquitin ligase and miRNA-106b dictates metastatic progression in pancreatic cancer. Oncotarget. 2016;7(2):1477-85.

44. Xiang W, He J, Huang C, Chen L, Tao D, Wu X, Wang M, Luo G, Xiao X, Zeng F, Jiang G. miR-106b-5p targets tumor suppressor gene SETD2 to inactive its function in clear cell renal cell carcinoma. Oncotarget. 2015;6(6):4066-79.

45. Liu F, Gong J, Huang W, Wang Z, Wang M, Yang J, Wu C, Wu Z, Han B. MicroRNA-106b-5p boosts glioma tumorigensis by targeting multiple tumor suppressor genes. Oncogene. 2014;33(40):4813-22.

46. Liu Y, Zhang J, Sun X, Li M. EMMPRIN down-regulating miR-106a/b modifies breast cancer stem-like cell properties via interaction with fibroblasts through STAT3 and HIF-1a. Sci Rep. 2016;6:28329.

47. Maimaiti A, Maimaiti A, Yang Y, Ma Y. MiR-106b exhibits an anti-angiogenic function by inhibiting STAT3 expression in endothelial cells. Lipids Health Dis. 2016:15:51.

\section{Submit your next manuscript to BioMed Central and we will help you at every step:}

- We accept pre-submission inquiries

- Our selector tool helps you to find the most relevant journal

- We provide round the clock customer support

- Convenient online submission

- Thorough peer review

- Inclusion in PubMed and all major indexing services

- Maximum visibility for your research

Submit your manuscript at www.biomedcentral.com/submit

) Biomed Central 